Revue bibliographique pour le domaine irano-aryen

\title{
Bob Langnas. "An Introduction to Parthian Silver Fractions, the Little Anomalies of Arsacid Coinage"
}

\section{Leonardo Gregoratti}

\section{(2) OpenEdition}

12 Journals

\section{Electronic version}

URL: http://journals.openedition.org/abstractairanica/49763

DOI: 10.4000/abstractairanica.49763

ISBN: 1961-960X

ISSN: 1961-960X

Publisher:

CNRS (UMR 7528 Mondes iraniens et indiens), Éditions de l'IFRI

\section{Electronic reference}

Leonardo Gregoratti, "Bob Langnas. "An Introduction to Parthian Silver Fractions, the Little Anomalies of Arsacid Coinage"', Abstracta Iranica [Online], Volume 40-41 | 2019, document 44, Online since 30 October 2019, connection on 19 April 2021. URL: http://journals.openedition.org/abstractairanica/ 49763 ; DOI: https://doi.org/10.4000/abstractairanica.49763

This text was automatically generated on 19 April 2021.

Tous droits réservés 


\title{
Bob Langnas. "An Introduction to Parthian Silver Fractions, the Little Anomalies of Arsacid Coinage"
}

\author{
Leonardo Gregoratti
}

\section{REFERENCES}

Bob Langnas. “An Introduction to Parthian Silver Fractions, the Little Anomalies of Arsacid Coinage", KOINON The International Journal of Classical Numismatic Studies, I, 2018, p. 114-140

1 The author in this paper analyses a typology of Parthian coins that seldom managed to catch the attention of the scholars: the drachm fractions. These specimens, hemidrachms (half of a drachm) diobols (1/3 drachm) and obols (1/6 drachm) are much less common than drachms and tetradrachms and were mint only by some Arsacid monarch in limited periods of Parthian history. Usually, their types replicate with few exceptions and modifications the types employed in the main issues: King's bust on the reverse and Arsakes/archer on the obverse. Before 1989 it was generally thought that Orodes II, in the 1st century BC, was the last Parthian great King to produce fractions of drachm. This fact had been connected to the gradual disappearance of Greek elements from Arsacid coinage and art. The discovery of the Shiraz hoard put into discussion this conviction: from that collection, fractions are attested for all monarchs between Vologases I and Osroses. Some scholars consider these specimens fully Parthian others ascribe them to a pro-Arsacid dynasty ruling part of Persis along with the local rulers. 


\section{AUTHORS}

\section{LEONARDO GREGORATTI}

Durham University 